Document downloaded from:

http://hdl.handle.net/10251/137885

This paper must be cited as:

Navarro, I.; Martí Albiñana, JV.; Yepes, V. (2019). Reliability-based maintenance optimization of corrosion preventive designs under a life cycle perspective. Environmental Impact Assessment Review. 74:23-34. https://doi.org/10.1016/j.eiar.2018.10.001

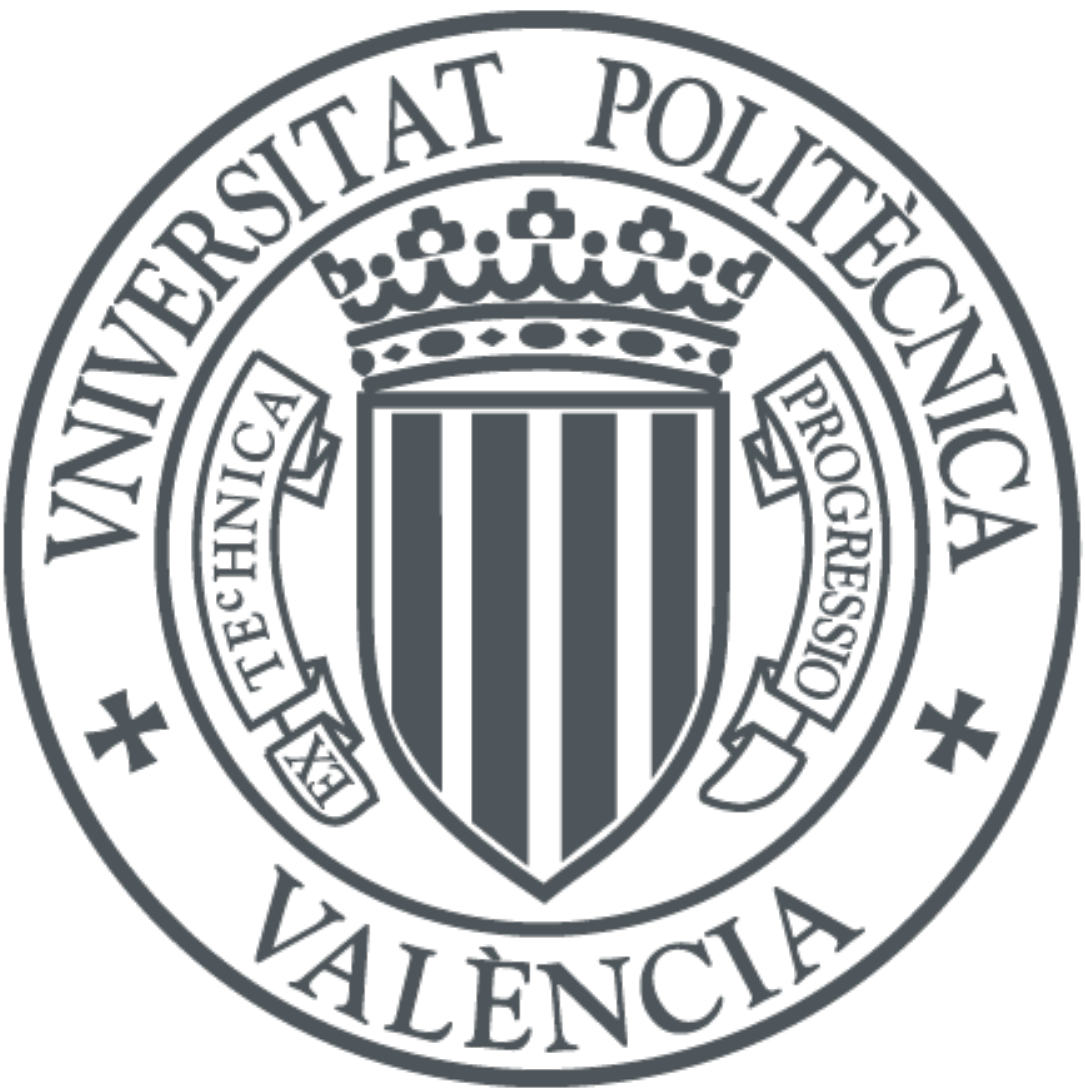

The final publication is available at

https://doi.org/10.1016/j.eiar.2018.10.001

Copyright Elsevier

Additional Information 


\title{
Reliability-based maintenance optimization of corrosion preventive designs under a life cycle perspective
}

\author{
Ignacio J. Navarro ${ }^{1}$ \\ José V. Martí \\ Víctor Yepes ${ }^{3}$
}

\begin{abstract}
Sustainability is of paramount importance when facing the design of long lasting, maintenance demanding structures. In particular, a sustainable life cycle design for concrete structure exposed to aggressive environments may lead to significant economic savings, and to reduced environmental consequences. The present study evaluates 18 different design alternatives for an existing concrete bridge deck exposed to chlorides, analyzing the economic and environmental impacts associated with each design as a function of the maintenance interval chosen. Results are illustrated in the context of a reliability-based maintenance optimization on both life cycle costs and life cycle environmental impacts. Maintenance optimization results in significant reductions of life cycle impacts if compared to the damage resulting from performing the maintenance actions when the end of the service life of the structure is reached. The use of concrete with $10 \%$ silica fume has been shown to be the most effective prevention strategy against corrosion of reinforcement steel in economic terms, reducing the life cycle costs of the original deck design by $76 \%$. From an environmental perspective, maintenance based on the hydrophobic treatment of the concrete deck surface results in the best performance, allowing for a reduction of the impacts associated with the original design by $82.8 \%$.
\end{abstract}

Keywords Life Cycle Assessment, Life Cycle Cost Analysis, Chloride corrosion, Sustainable design, Maintenance Optimization, Reliability

\section{Introduction}

Sustainability seeks to ensure on-going development without compromising the capacity of future generations to meet their own needs. In this context, the construction sector is one of the main environmental and economical stressors (Worrell et al., 2001); as such, special attention has been paid in recent years to sustainable design of structures. In particular, concrete bridges are the subject of particular interest in regard to the design approach, due to the existing long service life requirements and to the extensive material consumption associated with their construction and maintenance. Along the lines of sustainable structural design, research has been conducted on the cost optimization of concrete bridge design (García-Segura et al., 2014; Martí et al., 2013; Yepes et al., 2017), and also on the minimization of $\mathrm{CO}_{2}$ emissions and energy consumption (García-Segura et al., 2015; García-Segura and Yepes, 2016; Martí et al., 2016) resulting from bridge construction activities.

According to the long-term perspective on which the sustainability concept is based, life cycle assessment has become an internationally recognized method when dealing with the sustainable design of concrete bridges. Within this framework, the three pillars on which sustainability is based, namely society, environment and economy, have been covered to a greater or lesser extent. Hammervold et al. (2013) compare the life cycle environmental impacts of three bridges built in Norway, assuming routine repairs during the use phase. Zhang et al. (2016) include uncertainty in the evaluation of the environmental impacts.

\footnotetext{
${ }^{1}$ Graduate Research Assistant, Dept. of Construction Engineering, Universitat Politècnica de València, 46022 Valencia, Spain. E-mail: ignamar1 @ cam.upv.es

${ }^{2}$ Associate Professor, Institute of Concrete Science and Technology (ICITECH), Universitat Politècnica de València, 46022 Valencia, Spain. E-mail: jvmartia@cst.upv.es

${ }^{3}$ Professor, Institute of Concrete Science and Technology (ICITECH), Universitat Politècnica de València, 46022 Valencia, Spain. Corresponding author. Phone +34963879563; Fax: +34963877569; E-mail: vyepesp@cst.upv.es
} 
Du et al. (2014) and Penadés-Plà et al. (2017) compare alternative bridge designs from an environmental point of view. On the other hand, Eamon et al. (2012) compare the life cycle costs of reinforcement alternatives for concrete bridges. Navarro et al. (2018a) evaluate the costs associated with alternative bridge designs in coastal environments. A general conclusion is that the maintenance and use phase of a concrete bridge is the main source of impacts during its life cycle, both environmentally and economically. An adequate maintenance strategy is essential in order to reduce the life cycle impacts of the structure (Frangopol and Soliman, 2016). Studies have been carried out that optimize the maintenance costs of concrete bridges (Kendall et al., 2008; Safi et al., 2015; Frangopol, 2011). García-Segura et al. (2017) include environmental criteria in the maintenance optimization of bridge decks.

Maintenance and its impact are crucial for concrete structures in aggressive environments, where deterioration plays a major role over the term of their service life. Although there are several ways that concrete bridges may deteriorate in severe environments, experience shows that the most important threat to concrete structures is chloride-induced corrosion of the reinforcement (Valipour et al., 2017). Over the last few decades, different preventive measures have been developed to increase the corrosion resistance of concrete structures exposed to chlorides, thus leading to extended service lives and consequently to lower maintenance needs. However, lower maintenance needs do not always lead to the minimum of environmental and economic (Navarro et al., 2018a) impacts. A sustainable design of a concrete bridge in a coastal environment involves selecting the most suitable prevention alternative in terms of life cycle impacts, attending to the optimal maintenance strategy associated with it.

In this sense, this paper is devoted to shedding light on the way that different corrosion prevention measures may influence the results of optimum maintenance strategies from both the economic and the environmental points of view. To do so, a real concrete bridge deck subject to a marine environment is considered for the study. This bridge deck is modelled and assessed by means of both a life cycle cost analysis (LCCA henceforth) and an environmental life cycle impact analysis (LCA henceforth) with respect to a design service life of 100 years. Reliability-based maintenance optimization is performed for each of the analyzed preventive measures. Results will be presented and discussed for the optimal environmental and economic maintenance strategies.

\section{Materials and methods}

LCA is a widespread methodology that in recent years has taken firm root and been standarized (ISO, 2006a; ISO, 2006b) in the international context. LCCA, on the contrary, although in a fairly advanced stage of development (Hunkeler et al., 2008), still lacks an ISO standard that helps the integration of both assessment methodologies. In order to provide a comparative analysis on a consistent basis, the present study applies the ISO 14040 methodological framework for the LCC assessment (Swarr et al., 2011). According to ISO 14040, the assessment should be carried out in four phases: the definition of goal and scope, the inventory analysis, the impact assessment and the interpretation of the results.

\subsection{Goal and scope definition}

The present study focuses on particular preventive design alternatives applied to a real concrete bridge deck in a coastal environment. The bridge of Ensenada do Engano in Spain is analyzed. A cross-section of the bridge deck is shown in Fig. 1. The bridge, which is $721 \mathrm{~m}$ long and has a span distribution of $41 \mathrm{~m}+9 \mathrm{x}$ $70 \mathrm{~m}+50 \mathrm{~m}$, crosses over an estuary, with the deck less than $9 \mathrm{~m}$ above the mean sea level. The bridge consists of a box girder deck, with a section height of $3.2 \mathrm{~m}$ and a total width of $11 \mathrm{~m}$. The concrete cover of the deck is $30 \mathrm{~mm}$. The concrete mix of the deck is assumed to consist of a cement content of $400 \mathrm{~kg} / \mathrm{m}^{3}$, and a water/cement ratio of 0.45 . A passive reinforcing steel in the amount of $100 \mathrm{~kg} / \mathrm{m}^{3} \mathrm{of}$ concrete is considered. It shall be noted that, according to the Spanish design codes for marine environments, the bridge is designed to remain uncracked. This will be assumed for the rest of the study.

This study considers alternative designs for the described case study (called reference design or REF hereafter) based on the prevention strategies that are usually assumed for concrete structures exposed to marine environments. Firstly, increasing the original concrete cover of the steel reinforcement from $30 \mathrm{~mm}$ to $45 \mathrm{~mm}$ and to $55 \mathrm{~mm}$ (named here CC45 and CC55) has been considered. Secondly, a reduction in the water to cement ratio from the existing $\mathrm{w} / \mathrm{c}=0.45$ to $\mathrm{w} / \mathrm{c}=0.40$ and to $\mathrm{w} / \mathrm{c}=0.35$ (alternatives $\mathrm{W} / \mathrm{C} 40$ and W/C35 respectively) has also been considered. Reducing the water/cement ratio results in concretes with lower porosity, thus reducing the chloride diffusivity throughout the cover. The third type of preventive measure evaluated consists in the partial substitution of the concrete by fly ash or silica fume in the original 
concrete mixture. Additions of $10 \%$ and $20 \%$ fly ash (called here FA10 and FA20), and 5\% and 10\% silica fume (alternatives SF5 and SF10) have been considered. As with fly ash and silica fume additions, polymermodified concretes also result in denser concretes, thus contributing to an increase in the durability of concrete by hindering chloride diffusion. Consequentlly, additions $10 \%$ and $20 \%$ styrene butadiene rubber latex (designs PMC10 and PMC20) have been considered. The aforementioned percentages are expressed as a fraction of the cement content in the original mix. It shall be noted that the presented concrete mixes are assumed to replace completely the reference design mix.

The use of corrosion inhibitors is a usual way to extend the service lives of concrete structures in agressive environments. The present study considers two types of inhibitor, namely an organic inhibitor used as an additive to the original concrete mix (design OCI hereafter), and a migratory inhibitor, which is applied to the concrete surface and penetrates the concrete cover, thus reacting with the concrete and increasing its resistivity (alternative MIG). The study also evaluates the use of galvanized steel (design GALV) and stainless steel (design INOX) instead of the ordinary steel of the reference design in the bridge structure. The use of durable steels increases the amount of chlorides needed to start the corrosion process, thus extending the service life of the design. In addition, the application of a hydrophobic product to the exposed deck surface (alternative HYDRO) and the application of a sealant product (alternative SEAL) in order to prevent chloride ingress in the concrete cover have been considered. Finally, large structures in marine environments are also protected by means of impressed current cathodic protection (ICCP), where the reinforcing steel is forced to act as a cathode, thus preventing its oxidation. In summary, a total of 18 design alternatives, including the reference design, are taken into account in the performance evaluation. The resulting concrete mixes are shown in Table 1.

\subsubsection{Goal and scope of the study}

The goal of the present study is to evaluate and compare both the economic and environmental performance of the presented design alternatives for the concrete bridge deck in a coastal environment. The assessment is based on the impacts derived from a reliability-based maintenance approach, optimized for each design to minimize either the environmental or the economic life cycle impacts. This research aims at helping gain better insight into the impacts resulting from corrosion prevention designs of concrete structures, thus leading to better decisions in the early design stage.

\subsubsection{Functional unit}

Both assessments, LCCA and LCA, should be based on the same functional unit. The functional unit considered in this assessment is a $1 \mathrm{~m}$ length section of an $11 \mathrm{~m}$ wide concrete bridge deck serving to provide continuity to the existing coastal roadway at Ensenada do Engano, including the construction and maintenance activities for a service life of 100 years, as required by the Spanish Ministry of Public Works (2008). The deck that currently exists, the reference design as defined above, is assumed to provide the described functionality if an adequate level of maintenance is guaranteed. In order to make the assessments of the alternatives consistent and comparable, the functionality of every design is the same: an alternativespecific maintenance strategy is evaluated here to achieve the required service life, making the assessed designs equivalent in terms of durability. Maintenance consists in replacing the deteriorated concrete cover depth by a concrete with the same properties as the base concrete, thus not affecting the functionality of the system. Where hydrophobic and sealant surface treatments are considered, the maintenance consists in the periodical reapplication of these to the system, leaving the concrete cover unaffected.

However, the analyzed solutions shall provide not only the same service life but the same structural behavior as well. The reference design has a modulus of elasticity $E_{c}$ equal to $29 \mathrm{GPa}$, and a characteristic compressive strength $f_{c k}$ equal to $32 \mathrm{Mpa}$. Some of the evaluated alternatives are based on concrete mixes that result in different structural properties, as observed in Table 1. In order to make the resulting alternative concrete decks display the same deformability and strength than the reference design, the depth of some of the alternatives has been modified. Assuming the vertical deflection of the bridge mid-span section under service loads to be a measure of the deformability, section depths of the stiffer designs have been reduced. In particular, the designs $\mathrm{W} / \mathrm{C} 40, \mathrm{PMC} 10$ and PMC20 have resulted in $3.04 \mathrm{~m}$ deep box girder sections, while the alternative W/C35 has a depth of $2.89 \mathrm{~m}$ to make these designs equally deformable as the reference design. The reference bending strength is achieved in these modified sections by slightly increasing the pre-stress force. 


\subsubsection{System boundaries}

The system boundary definition can substantially affect the results of LCCA and LCA. The same system has been considered for both assessments, covering from the production of the construction materials needed both for the construction and for the maintenance and use phase of the deck, to the end of the required service life, following a "gate-to-grave" approach. As usual for a comparison-oriented assessment, and according to the cut-off criteria established in ISO (2006b), processes that are considered as identical between alternatives are excluded from the analysis (Martínez-Blanco et al., 2014, Navarro et al., 2018b). Processes considered to be identical between alternatives include the execution of the road pavement, the wall parapets of the deck, the prestressing tendons, the installation of the adequate lighting spots or the painting works, as well as their respective maintenance needs throughout the required 100 years service life. The present study only takes into consideration those activities that are different between the alternatives, which are those related to both the different materials consumed in the construction and repair processes of the reinforced concrete deck shown in Fig. 1 and the number of maintenance activities resulting from the optimized strategy selected. Environmental impacts related to the demolition stage have also been considered, derived from the recycling treatments of waste concrete and steel, as well as from the secondary life of crushed concrete. Fig. 2 shows the system boundaries considered in both the LCCA and LCA.

\subsection{Inventory analysis}

The inventory data assumed in the environmental characterization of the production activities of the different construction materials, such as cement, aggregates, reinforcement steel or polymers, have been gathered from the environmental database Ecoinvent 3.2. Table 2 presents the Ecoinvent datasets to which the different construction materials related to the different alternative designs have been assimilated. This information has been complemented with data on specific concepts, such as machinery performance and fuel demand values. Table 3 shows the assumed values, which have been obtained from the existing literature and from machinery manufacturers. The impacts derived from the use of silica fume and fly ash additions, as by-products of industry, have been economically allocated as suggested by Chen (2009) and Chen et al. (2010). Consequently, the impact derived from the use of fly ash is $1 \%$ of the impact resulting from the electricity production that results in the generation of $1 \mathrm{~kg}$ fly ash, while for silica fume, an allocation of $4.8 \%$ of the impact derived from the production of the ferrosilicon needed to generate $1 \mathrm{~kg}$ silica fume is considered.

Transport distances between the different production facilities and the installation site have been estimated taking into consideration the location of the nearest material providers to the Engano Bridge. Table 4 shows the assumed transport distances. Materials are assumed to be transported between locations by lorry. However, when the production center is located more than $100 \mathrm{~km}$ away from the construction site, it is assumed that only $20 \%$ of the distance is travelled by lorry, while the rest of the transport is done by freight train.

In the environmental assessment, it is assumed that the concrete of the cover demolished after each maintenance activity, and the waste concrete resulting from the structure demolition at the end of life stage, are crushed into $200 \mathrm{~mm}$ boulders and recycled to serve as embankment protection. The environmental impacts derived from the end-of-life treatment of the concrete cover removed during the maintenance activities, as well as for the waste concrete and reinforcing steel after the demolition of the deck after the 100 years service life has been considered in the present study. Ecoinvent concepts "treatment of waste concrete, not reinforced, sorting plant" and "treatment of waste reinforcing steel, sorting plant" have been considered in the present study fur such purpose.

The surface of the concrete disposed as embankment protection tends to absorb atmospheric $\mathrm{CO}_{2}$ from the atmosphere as a result of the so-called carbonation process, thus resulting in positive environmental impacts during the concretes secondary life following each deck cover removal or the final bridge demolition. This $\mathrm{CO}_{2}$ uptake can be calculated as follows (Collins, 2010):

$\mathrm{CO}_{2(\text { uptake, in } \mathrm{kg})}=c \cdot \mathrm{CaO} \cdot r \cdot A \cdot M \cdot k \cdot \sqrt{t} \cdot\left(\frac{t_{0}}{t}\right)^{0.106}$

where $c$ is the cement content $\left(\mathrm{kg} / \mathrm{m}^{3}\right), \mathrm{CaO}$ is a parameter assumed to be 0.65 (García-Segura et al., 2014), which represents the calcium oxide contained in Portland concrete, $r$ is the amount of $\mathrm{CaO}$ that absorbs 
$\mathrm{CO}_{2}$ and is assumed to be 0.75 according to Lagerblad (2005), $A$ is the concrete surface exposed to air, $M$ is the molar fraction $\mathrm{CO}_{2} / \mathrm{CaO}$ (assumed to be 0.79 ), $t$ is the exposure time (years), $t_{0}$ is the time of reference in years (assumed to be 0.0767 years) and $k$ is the carbon rate coefficient, which is material dependent. The assumed values for the carbon rate coefficients are shown in Table 5. In the present study, the duration of the secondary life of the recycled concrete is assumed to be 30 years.

Regarding the inventory data considered in the LCCA, the cost data have been gathered from the construction cost database developed by CYPE (CYPE Ingenieros S.L., Alicante, Spain). This database is constantly updated and considers the costs of materials, machinery and labour, as well as indirect costs for the different construction and maintenance activities that are usual in the Spanish construction sector. The present LCCA assumes the performance values adopted for machinery in the LCA. The assumed unit costs for each concept are shown in Table 6. As the analyzed system is located in Spain, the currency chosen for the assessment is the Euro (€).

It shall be noted that, although sharing the same system boundaries with LCA, the background processes are assumed to be indirectly reflected in the considered element prices (Martínez-Blanco et al., 2014). Thus, although costs are provided for foreground processes, namely production activities and construction and maintenance operations, it is assumed that producers and material providers include in these concepts all of the costs of the chain processes along the product's life cycle, such as energy consumption or raw materials extraction.

The costs considered are up to date as of year 2018. The different design alternatives, according to the expected durability performance, will incur in future costs at different times. In order to make these impacts comparable with each other, the future costs are discounted and converted into present (2018) values. It is important to note here that there is no consensus on which discount rate is most appropriate for each particular project under study. High discount rates will emphasize the near future, thus resulting in assessments in which the future effects are almost negligible from an economic point of view. This perspective is not coherent with assessments focused on sustainable designs. Therefore, preference is usually given to the use social discount rates, which are lower than private rates (Allacker, 2012). A discount rate of $2 \%$ is chosen for the present LCCA.

\subsection{Life cycle impact assessment}

The assessment of the life cycle environmental impacts associated with the alternative deck designs under evaluation is conducted considering the ReCiPe 2008 assessment methodology (Goedkoop et al., 2009), which combines the midpoint approach of CML method and the endpoint approach of Eco-Indicator 99. ReCiPe is applied here from a hierarchist perspective, a consensus model between the short-term focused individualist and the long-term focused egalitarian perspectives. The impacts are weighted and normalized using the ReCiPe Europe Endpoint H/A set so as to integrate the different impact categories into a single score.

With regard to the LCCA, and according to Swarr et al. (2011), as all inventory data in an LCCA are expressed by a single unit of measure, namely the adopted currency, there is no assessment phase as such, where a particular characterization or normalization of the inventory data is needed. For the same reason, weighting between cost categories has not been considered either (Özkan et al., 2016).

\section{Reliability-based maintenance optimization}

\subsection{Service life prediction}

Concrete deterioration in marine environments occurs when chloride ions reach the reinforcing bars in sufficient concentration to trigger steel corrosion. This critical threshold is known as the critical chloride content $\left(C_{c r}\right)$ and depends mainly on the properties of the rebars. To evaluate the chloride concentrations at the reinforcements over time, the Fickean model proposed in Fib Bulletin 34 (Fib, 2006) is considered. This model assumes chlorides to ingress the concrete cover as a result of a diffussive process, and allows the evolution of the chloride concentration at the reinforcing bars at any time to be evaluated. As shown by Titi and Biondini (2016), reinforcing bars at the section corners are more prone to corrosion than the rest of the rebars, due to the so-called corner effect. Consequently, the one-dimensional model suggested in Fib (2006) has been adapted to consider the case where a reinforcing steel bar is exposed to two chloride fronts 
advancing simultaneously. The chloride concentration $C$ at a particular time $t$ and at any depth in both $x$ and $y$ directions of the evaluated cross-section shall then be expressed as:

$C(x, y, t)=C_{S} \cdot\left(1-\operatorname{erf} \frac{x}{2 \sqrt{D_{0, x} \cdot\left(\frac{t_{0}}{t}\right)^{\alpha} \cdot t}} \cdot \operatorname{erf} \frac{y}{2 \sqrt{D_{0, y} \cdot\left(\frac{t_{0}}{t}\right)^{\alpha} \cdot t}}\right)$

where $C(x, y, t)$ is the chloride concentration (wt.\%/binder) at a particular position in the concrete depth [x, y] (mm) at time $t$ (years); $C_{s}$ is the surface chloride concentration (wt.\%/binder); $\operatorname{erf}($.) is the Gauss error function; $D_{0}$ is the chloride diffusion coefficient ( $\mathrm{mm}^{2} /$ years). It has been assumed that the concrete is homogeneous and that the chloride diffusivity in both directions is the same $\left(D_{0, x}=D_{0, y}\right)$. The age factor $\alpha$ has been assumed to be 0.5 , as proposed in the Spanish concrete design code (Spanish Ministry of Public Works, 2008). The reference time $t_{0}$, expressed in years, is considered to be 28 days $\left(t_{0}=0.0767\right.$ years). The concrete cover in the y-direction $\left(r_{y}\right)$ for the most exposed corner rebar is assumed constant and equal to $50 \mathrm{~mm}$ for each of the analyzed designs, while the cover in the $\mathrm{x}$-direction $\left(r_{x}\right)$ varies depending on the prevention design considered. Considering the distance existing between the sea water surface and the deck, a surface chloride content of $C_{s, 0}=2.88 \%$ is assumed for the case study (Spanish Ministry of Public Works, 2008).

The parameter values for the durability characterization of each design alternative have been obtained from the literature. Table 7 shows the mean and the standard deviation values assumed for both the critical chloride content and the diffusion coefficients considered for the different materials, as well as the resulting mean time to failure for each of the alternatives, in years. Parameters are assumed to follow a Gaussian distribution.

\subsection{Maintenance optimization problem}

The adoption of an adequate maintenance strategy is essential to reduce the economic and environmental impacts resulting from an excessive level of deterioration of the structure. To prevent steel rebars becoming corroded, it is common practice to undertake maintenance operations before the critical chloride content is reached at the position of the rebars. From such a preventive perspective, maintenance is reduced to simply demolishing and regenerating the concrete cover only to the depth where the critical chloride threshold has been exceeded, thus it is not necessary to replace the embedded steel and incur in unnecessary economic and environmental impacts.

Maintenance optimization consists in finding the specific maintenance interval that minimizes the economic or environmental impacts at the end of the service life of the structure, while ensuring an adequate level of reliability. Here, maintenance is assumed to be carried out at a fixed regular interval $T_{\text {opt }}$, different for each alternative under study. The magnitude of the impacts derived from a particular maintenance operation is then proportional to the depth reached by the chlorides at the time when maintenance is performed.

The reliability index $\beta$ of the structure at a specific time depends on the advance of the chloride front at that time and on the associated probability of failure $\left(p_{f}\right)$. In the context of preventive maintenance, failure is assumed to occur when the chloride concentration at the rebars exceeds the critical threshold $C_{c r}$. The optimization problem for new bridges consists in finding, for each of the alternative designs under evaluation, the maintenance interval $T_{o p t}$ that minimizes the total expected impacts under reliability constraints. Thus the optimization problem is formulated as follows:

\section{Given}

The durability characterization of the alternative under study, provided by the critical chloride content $C_{c r}$, the surface chloride concentration $C_{s}$, the chloride diffusion coefficient $D_{0}$ and the concrete cover $\mathrm{r}_{\mathrm{x}}$.

\section{Goal}

Find the optimal maintenance interval $T_{\text {opt }}$ so that the impacts derived from the life cycle phases of construction, maintenance and demolition are minimal.

\section{Subject to}


The reliability at the time of maintenance shall not exceed the minimum annual target reliability index:

$\beta\left(T_{\text {opt }}\right)=-\phi^{-1}\left[p_{f}\left(T_{o p t}\right)\right] \leq \beta_{\text {lim }}$

where $\Phi^{-1}$ is the inverse of the Gaussian cumulative distribution function of the probability of failure at time $T_{\text {opt }}$, and $\beta_{\text {lim }}$ is the minimum annual reliability index required to guarantee a proper condition of the bridge during its entire service life. Following Nogueira et al. (2012), a value of 1.30 is assumed in the present study for the target reliability. The present study assumes that maintenance restores the durability performance of the deck to its original state. Consequently, once maintenance is carried out, the reliability of the deck returns to its initial value. Monte Carlo simulation is used to obtain the probability of failure needed to evaluate the reliability index for each of the analyzed measures at any time.

\section{Results and discussion}

Results are analyzed under two different scenarios. The first evaluates both the economic and the environmental life cycle impacts assuming a maintenance strategy that minimizes the LCCA results of every alternative. The second scenario assumes, for the different designs, maintenance strategies focused on minimizing the environmental life cycle impacts. In both cases, and considering the uncertainty associated with each of the durability parameters, 20000 Monte Carlo simulations have been performed to ensure that the results converge, resulting in a relative error of the estimation of $0.5 \%$.

\subsection{Assessment results under economically optimized maintenance}

Fig. 3 shows the assessment results of both LCCA and LCA considering the maintenance intervals for each alternative associated with minimum life cycle costs. The results presented are sorted from the most to the least expensive design, considering a period of analysis of 100 years. In accordance with the definition of the functional unit of the present assessment, the results are presented as mean impacts per longitudinal meter of deck.

It is observed that the most expensive prevention alternative is the reference measure (REF), namely the original deck design, followed by the alternatives PMC10 and GALV. It can be seen that, for the particular case evaluated, any of the analyzed preventive designs would allow us to reduce the life cycle costs significantly. The addition of $10 \%$ polymer to the original concrete mix (PMC10) or the substitution of ordinary steel reinforcement by galvanized bars (GALV) leads to designs which are between $16 \%$ and $36 \%$ lower in cost than the original design, respectively. From the results obtained, it is clear that, among the alternatives evaluated in this study, the optimal prevention alternative in terms of life cycle costs is SF10, which consists in the addition of $10 \%$ silica fume to the original concrete mix and the partial substitution of the cement content. The cost of this solution is $24 \%$ of the life cycle cost of the original design. This design is followed by the use of migrating inhibitors, which results, via LCCA, in $27 \%$ of the costs associated with the reference solution. The surface treatments (alternatives HYDRO and SEAL) are also very cost-efficient measures in the long term, generating life cycle costs of approximately 31 to $33 \%$ of the costs associated with the reference measure.

Table 8 shows the intermediate results related to the cost optimization calculation. It is common to undertake maintenance actions only when the end of the service life of the structure has been reached and not before, under the false assumption that less maintenance will lead to lower costs at the end of the life cycle. It is observed that, in general, it cannot be said that alternatives with shorter maintenance intervals show greater life cycle costs. Indeed, it is observed that surface treatments with hydrophobic products (HYDRO) and designs with polymers (PMC10), which have the same maintenance optimum interval, have completely different LCCA costs. So, although this statement is true for alternatives belonging to the same design family (CC45 and CC55, or W/C40 and W/C35), when comparing alternatives of a different nature, the costs associated with the different materials and repair processes play a major role. Table 8 presents the economic impacts due to installation and maintenance for the different designs. The economic impacts derived from demolition have not been included due to the reason that, when discounted, its effect can be neglected when compared to the impacts across the rest of the life cycle. It can be concluded that, in general, the economic impact of the maintenance and use phase is essential in the LCC assessment, taking up to $85 \%$ of the total life cycle costs in some cases. Similar results have been reported by Navarro et al. (2018a). 
Table 8 shows for each alternative how much the resulting life cycle impact has been reduced by selecting the optimum interval for maintenance with respect to the impact resulting from performing maintenance only at the end of the service life for each design. It is observed that the optimization leads to a reduction of the life cycle costs that reaches up to 10 to $11 \%$ in some cases.

\subsection{Assessment results under environmentally optimized maintenance}

Fig. 4 shows the environmental and economic assessment results when the maintenance strategy is selected in order to minimize life cycle environmental impacts. Again, the results presented in Fig. 4 are sorted in descending order according to the resulting environmental impacts of each design throughout a period of analysis of 100 years. All the results are presented as mean impacts per longitudinal meter of deck.

The greatest life cycle environmental impacts are associated with the reference design (REF), followed by alternatives PMC10 and INOX. It is interesting how alternatives with great durability such as show such life cycle results. According to Mistry et al. (2016), the high impacts resulting from the use of stainless steel are mainly derived from the affection of the manufacturing process to the quality of the ecosystem. On the other hand, the impacts associated with alternative PMC results from the extraction process associated with the production of styrene butadiene latex. On the other hand, the most environmentally friendly alternative among those evaluated in the present study is HYDRO, whose life cycle environmental impact is $21.3 \%$ of the impact of the reference alternative. This measure is followed by a number of designs that result in very similar LCA results, namely those based on sealant surface treatments (SEAL), cathodic protection (ICCP), migrating inhibitors (MIG), and silica fume additions (SF10), whose impacts range between $23.3 \%$ and $29.1 \%$ of the original design impact, respectively. It should be noted that, similar to what is observed for the cost optimization results, the application of any of the analyzed preventive measures allows us to reduce the life cycle environmental impacts.

Table 9 shows the intermediate results associated with the environmental maintenance optimization. It is observed that optimization in environmental terms leads to greater impact reductions, reaching a reduction of up to $23 \%$ of the impacts derived from performing maintenance actions only at the end of the service life of the design. As with LCC assessment results, it is observed that the relative importance of maintenance is essential for the minimization of the total impact of any preventive solution, as this impact is shown to be proportional to the number of maintenance operations required for the alternative evaluated. Exceptions to this are alternatives HYDRO and SEAL, which in fact require very intensive maintenance and generate very low environmental impacts. This result is based on the fact that the assumed maintenance operations for surface treatments imply less damage to the environment than the replacement of the concrete cover needed in the maintenance of the other alternatives. The impacts derived from demolition are also presented. Only those impacts derived from transport and recycling of waste materials are considered, neglecting those associated to machinery and energy consumption, which are considered identical between alternatives.

\subsection{Analysis of the Pareto Front}

Results have been presented considering those maintenance intervals that minimize either the environmental or the economic life cycle impacts of each alternative under study. However, it is possible to find other solutions that, not being the absolute optimum in either of the two impact areas considered, may provide an optimum in overall terms. Taking into consideration every feasible combination between alternatives and maintenance intervals, the Pareto principle is used to identify those optimal solutions. Fig. 5 shows the Pareto front of the alternatives under study. It is observed that the results present, in general, an almost linear behavior, which means that economic and environmental impacts are proportional. This can also be appreciated in Tables 8 and 9, where it is observed that the maintenance intervals that minimize impacts from an LCCA and LCA perspective are very close.

The Pareto optimal set consists of five alternatives. Two of the alternatives are the optima described above for environmental and economic terms, namely designs HYDRO and SF10 with maintenance intervals of 5 and 34 years respectively. The optimal set is completed with alternatives MIG (with a maintenance interval of 34 years), SEAL (reapplied every 5 years) and HYDRO (with a maintenance interval of 4 years). From the analysis of the optimal set, it is shown that designs based on surface treatments are very competitive in environmental terms, which is a consequence of the lower emissions and energy consumption derived from the machinery involved in the reapplication of the treatments in contrast to the 
impacts resulting from concrete replacement. Similar results have been previously reported in the existing literature (Petcherdchoo, 2012; Petcherdchoo, 2015). On the other hand, the advantage of solutions based on concrete with silica fume (SF10) and corrosion inhibitors (MIG) relies on their high durability.

\subsection{Uncertainty analysis of the results}

Due to the complexity and long life spans of concrete bridge structures, the assessment of their life cycle impacts is subject to high levels of uncertainty. Analyzing the sensitivity of the assessment results with regard to variations in particular key factors is therefore of great importance to validate the conclusions derived from such studies. Tables 8 and 9 show, for the economic and the environmental assessment respectively, the confidence intervals of the life cycle results obtained for each alternative.

With respect to the environmental results, the uncertainty associated with each of the considered datasets is defined in accordance with Ecoinvent database, which takes into consideration different aspects that might influence the input values, such as geographic representativeness or measurement inaccuracies at production locations. From the results presented in Table 9 it is derived that the estimations of the environmental impacts have coefficients of variation (COV) that fall below $5 \%$ for every alternative under evaluation. Regarding the economic assessment, the considered costs have been assigned a normal probability distribution with a variance of 0.15 . As a consequence, economic results have slightly greater uncertainty, as their COV reach up to $12 \%$ for the worst case (REF), due to the reduced maintenance interval and the consequently greater number of repair activities to be considered in the evaluation.

In addition, two main sources of uncertainty are evaluated here: the considered LCA methodology chosen for the environmental assessment and the discount rate assumed for the LCCA. The discount rate chosen for LCCA is one of the main contributors on the assessment results, and therefore a critical source of uncertainty (Lee et al., 2011; Harvey et al., 2012). A sensitivity analysis of this parameter is performed to evaluate its effect on the Pareto set of optimal solutions obtained for the assumed discount rate of $2 \%$. Two new discount rates are chosen within the usual range of European infrastructures, namely $3 \%$ and $4 \%$. For these two new scenarios, the Pareto sets have been recalculated and are shown in Table 10. Results show that, regardless of the discount rate considered, the set of optimal solutions consists of the same alternative designs, namely SF10, MIG, SEAL and HYDRO. Slight differences are to be found, however, in the optimal maintenance interval: it can be observed that for a discount rate of $4 \%$, the Pareto set consists of 7 solutions, with maintenance intervals that tend to be longer than when considering reduced discount rates. This is due to the fact that the greater the chosen discount rate, the less importance is given to future costs, thus promoting solutions with costs distant in time.

The LCA methodology chosen in the impact assessment is considered to be a great source of uncertainty as well (Cellura et al., 2011; Hung and Ma, 2009). Taking this into consideration, two different impact assessment methods are evaluated, namely EPS (which stands for Environmental Priority Strategies) and the Eco-Indicator 99. These methods have been chosen in this sensitivity study due to the fact that they allow the estimation of the environmental performance of a system in one single endpoint indicator. The Pareto sets resulting from the use of these methodologies are shown in Table 11. From the results it is concluded that the solutions conforming the Pareto set are not significantly sensitive to the environmental impact assessment methodology chosen. It shall be observed, however, that the sealant surface treatment is discarded from the Pareto set when using Eco-Indicator 99 method.

In view of the presented results, the conclusions of the present comparative study shall be considered robust and not sensitive to the analyzed sources of uncertainty.

\section{Conclusions}

The present study assesses the life cycle environmental and economic impacts derived from the different design alternatives that are usual for concrete structures in marine environments. In particular, the performance of 17 corrosion preventive designs are evaluated as alternatives to the current design of the bridge deck at Ensenada do Engano in Spain. The study focuses on the particular maintenance intervals that minimize the impacts along the life cycle of the structure under evaluation, assuming a reliability-based maintenance optimization. From the obtained results it is concluded that the impacts derived from the maintenance phase of a structure can be critical with respect to the resulting life cycle impacts, as was the case here. It has been observed that the optimization of the maintenance intervals reduces the economic and 
environmental life cycle impacts up to 13 and $19 \%$, respectively, if compared to the usual strategy where maintenance is performed only when the end of the service life of the structure is reached.

However, excepting the case using stainless steel rebars, and irrespective of the material and installation costs and impacts, every prevention design considered in this study reduces both the economic and the environmental impacts throughout the service life of the bridge deck when compared to the impacts associated with the durability design of the actual bridge. It has been shown that, among the options considered, designs based on silica fume additions (SF10), hydrophobic surface treatment (HYDRO) and the use of migrating inhibitors (MIG) comprise the optimal set. In relation to the reference design, the use of concretes with the addition of $10 \%$ silica fume allows for a reduction of the economic and environmental impacts of $74 \%$ and $78 \%$ respectively. On the other hand, designs based on the periodic application of hydrophobic surface treatment result in reductions of the life cycle impacts of up to $67 \%$ from an economic perspective, and $82 \%$ in the environmental field.

The present study evaluates the sustainability of alternative corrosion preventive designs considering both an environmental and an economic approach, taking into consideration the impacts derived from the construction, the maintenance and the end of life phases. Further research is required to effectively incorporate the third pillar of sustainable design, namely the social dimension, in the evaluation of prevention strategies for concrete bridge decks. In addition, the present work is limited to the sustainability assessment of a single bridge, not considering the rest of the elements of the infrastructure network in which it is included. Future works shall therefore be oriented to consider the assessment of sustainable maintenance strategies for a particular bridge within the framework of a bridge management system.

\section{Acknowledgements}

The authors acknowledge the financial support of the Spanish Ministry of Economy and Competitiveness, along with FEDER funding (Project: BIA2017-85098-R).

\section{References}

Allacker, A., 2012. Environmental and economic optimisation of the floor on grade in residential buildings. Int. J. Life Cycle Assess. 17, 813-827. https://dx.doi.org/10.1007/s11367-012-0402-2.

Bertolini, L., Bolzoni, F., Pastore, T., Pedeferri, P., 1996. Behaviour of stainless steel in simulated concrete pore solution. Br. Corros. J. 31, 218-22. https://dx.doi.org/doi:10.1179/000705996798114572.

Bertolini, L., Bolzoni, F., Gastaldi, M., Pastore, T., Pedeferri, P., Redaelli, E., 2009. Effects of cathodic prevention on the chloride threshold for steel corrosion in concrete. Electrochim. Acta, 54, $1452-$ 1463. https://dx.doi.org/10.1016/j.electacta.2008.09.033.

Blakey, S.G., Beck, S.B.M., 2004. Energy consumption and capacity utilization of galvanizing furnaces. Proc. Inst. Mech. Eng. Part E J. Process. Mech. Eng. 218, 251-9. https://dx.doi.org/10.1243/0954408042466927.

Bolzoni, F., Brenna, A., Fumagalli, G., Goidanich, S., Lazzari, L., Ormellese, M., Pedeferri, M. P., 2014. Experiences on corrosion inhibitors for reinforced concrete. Int. J. Corros. Scale Inhib., 3, 254 278. https://dx.doi.org/10.17675/2305-6894-2014-3-4-254-278.

Cellura, M., Longo, S., Mistretta, M., 2011. Sensitivity analysis to quantify uncertainty in Life Cycle Assessment: The case study of an Italian tile. Renew. Sust. Energ. Rev., 15, 4697 - 4705. https://doi.org/10.1016/j.rser.2011.07.082.

Cheewaket, T., Jaturapitakkul, C., Chalee, W., 2014. Concrete durability presented by acceptable chloride level and chloride diffusion coefficient in concrete: 10-year results in marine site. Mater. Struct. 47, 1501-11. https://dx.doi.org/10.1617/s11527-013-0131-4.

Chen, C., 2009. A study of traditional and alternative structural concretes by means of the life cycle assessment method, $\mathrm{PhD}$ thesis (Troyes, University of Technology of Troyes). 
Chen, C., Habert, G., Bouzidi, Y., Jullien, A., Ventura, A., 2010. LCA allocation procedure used as an incitative method for waste recycling: An application to mineral additions in concrete. Resour. Conserv. Recycl. 54, 1231-1240. https://dx.doi.org/10.1016/j.resconrec.2010.04.001.

Collins, F., 2010. Inclusion of carbonation during the life cycle of built and recycled concrete: influence on their carbon footprint. Int. J. Life-cycle Assess. 15, 549-556. https://dx.doi.org/10.1007/s11367010-0191-4.

Darwin, D., Browning, J., O’Reilly, M., Xing, L., Ji, J., 2009. Critical Chloride Corrosion Threshold of Galvanized Reinforcing Bars. ACI Mater. J. 106, 176-83. https://dx.doi.org/10.14359/56465.

Du, G., Safi, M., Pettersson, L., Karoumi, R., 2014. Life cycle assessment as a decision support tool for bridge procurement: environmental impact comparison among five bridge designs. Int. J. Lifecycle Assess. 19(12), 1948-1964. https://dx.doi.org/10.1007/s11367-014-0797-z.

Eamon, C. D., Jensen, E. A., Grace, N. F., Shi, X., 2012. Life-Cycle Cost Analysis of Alternative Reinforcement Materials for Bridge Superstructures Considering Cost and Maintenance Uncertainties. J. Mater. Civ. Eng. 24, 373-380. https://dx.doi.org/10.1061/(ASCE)MT.19435533.0000398.

Fib. Fib Bulletin 34, 2006. Model code for service life design. Lausanne: Fib.

Frangopol, D. M., Soliman, M., 2016. Life-cycle of structural systems: recent achievements and future directions. Struct. Infrastruct. Eng. 12, 1-20. https://dx.doi.org/10.1080/15732479.2014.999794.

Frangopol, D.M., 2011. Life-cycle performance, management, and optimisation of structural systems under uncertainty: accomplishments and challenges. Struct. Infrastruct. Eng. 7, 389-413. https://dx.doi.org/10.1080/ 15732471003594427.

Frederiksen, J. M., 2000. Chloride threshold values for service life design. Second International RILEM Workshop on Testing and Modelling the Chloride Ingress into Concrete : Paris, France, 11-12 September 2000. RILEM Publications.

García-Segura, T., Yepes, V., 2016. Multiobjective optimization of post-tensioned concrete box girder road bridges considering cost, CO2 emissions, and safety. Eng. Struct. 125, 325-36. http://dx.doi.org/10.1016/j.engstruct.2016.07.012.

García-Segura, T., Yepes, V., Alcalá, J., Pérez-López, E., 2015. Hybrid harmony search for sustainable design of post-tensioned concrete box-girder pedestrian bridges. Eng. Struct. 92, 112-22. http://dx.doi.org/10.1016/j.engstruct.2015.03.015.

García-Segura, T., Yepes, V., Frangopol, D.M., Yang, D.Y., 2017. Lifetime Reliability-Based Optimization of Post-Tensioned Box-Girder Bridges. Eng. Struct., 145, 381-91. https://dx.doi.org/10.1016/j.engstruct.2017.05.013.

García-Segura, T., Yepes, V., Martí, J.V., Alcalá, J., 2014. Optimization of concrete I-beams using a new hybrid glowworm swarm algorithm. Lat. Am. J. Solids. Struct. 11, 1190-205. http://dx.doi.org/10.1590/S1679-78252014000700007.

Goedkoop, M., Heijungs, R., Huijbregts, M., De Schryver, A., Struijs, J., Van Zelm, R., 2009. ReCiPe 2008 First Edition Report I: Characterisation.

Hammervold, J., Reenaas, M., BrattebØ, H., 2013. Environmental life cycle assessment of bridges. J. Bridge Eng. 18, 153-161. doi: 10.1061/(ASCE)BE.1943-5592.0000328.

Harvey, J.T., Rezaei, A., Lee, C., 2012. Probabilistic approach to Life Cycle Cost Analysis of preventive maintenance strategies on flexible pavements. Transp. Res. Rec. J. Transp. Res. Board, 2292, 6172. https://doi.org/10.3141/2292-08.

Hung, M.L., Ma, H., 2009. Quantifying system uncertainty of life cycle assessment based on Monte Carlo simulation. Int. J. Life-cycle Assess., 14, 19-27. https://doi.org/ 10.1007/s11367-008-0034-8. 
Hunkeler, D., Lichtenvort, K., Rebitzer, G., Ciroth, A., Huppes, G., Klöpffer, W., Rüdenauer, I., Steen, B., Swarr, T., 2008. Environmental life cycle costing. SETAC Publications, Brussels. ISBN: 9781420054705.

ISO (2006a) Environmental management:-life cycle assessment- principles and framework. International Standards Organization, ISO 14040: 2006, Geneva.

ISO (2006b) Environmental management-life cycle assessment - requirements and guidelines. International Organisation for Standardisation, ISO 14044:2006, Geneva.

Kendall, A., Keoleian, G. A., Helfand, G. E., 2008. Integrated life-cycle assessment and lifecycle cost analysis model for concrete bridge deck applications. J. Infrastruct. Syst. 14, 214-22. https://dx.doi.org/10.1061/(ASCE)1076-0342(2008) 14:3 (214).

Lagerblad, B., 2005. Carbon dioxide uptake during concrete life-cycle: State of the art. Swedish Cement and Concrete Research Institute, Stockholm.

Lee, E.B., Kim, C., Harvey, J.T., 2011. Value analysis using performance attributes matrix for highway rehabilitation projects: California Interstate 80 Sacramento case. Transp. Res. Rec. J. Transp. Res. Board 2228, 23-32. https://doi.org/10.3141/2227-03.

Martí, J.V., García-Segura, T., Yepes, V., 2016. Structural design of precast-prestressed concrete U beam road bridges based on embodied energy. J. Clean. Prod. 120, 231-40. http://dx.doi.org/10.1016/j.jclepro.2016.02.024.

Martí, J.V., González-Vidosa, F., Yepes, V., Alcalá, J., 2013. Design of prestressed concrete precast road bridges with hybrid simulated annealing. Eng. Struct. 48, 342-52. http://dx.doi.org/10.1016/j.engstruct.2012.09.014.

Martínez-Blanco, J., Lehmann, A., Muñoz, P., Antón, A., Traverso, M., Rieradevall, J., Finkbeiner, M., 2014. Application challenges for the social life cycle assessment of fertilizers within life cycle sustainability assessment. J. Clean. Prod. 69, 34-48. https://dx.doi.org/10.1016/j.jclepro.2014.01.044.

Medeiros, M., Castro-Borges, P., Aleixo, D., Quarcioni, V.A., Marcondes, C., Helene, P., 2012. Reducing water and chloride penetration through silicate treatments for concrete as a mean to control corrosion kinetics. Int. J. Electrochem. Sci. 7, 9682-9696. httpss://dx.doi.org/10.1016/S09500618(00)00043-X.

Millman, L.R., Giancaspro, J.W., 2012. Environmental Evaluation of Abrasive Blasting with Sand, Water, and Dry Ice. Int. J. Archit. Eng. Constr. 1, 174-82. https://dx.doi.org/10.7492/IJAEC.2012.019.

Mistry, M., Koffler, C.,Wong, S., 2016. LCA and LCC of the world's longest pier: a case study on nickelcontaining stainless steel rebar. Int. J. Life Cycle Assess. 21, 1637e1644. https://doi.org/10.1007/s11367-016-1080-2.

Navarro, I.J., Yepes, V., Martí, J.V., 2018a. Life Cycle Cost Assessment of preventive strategies applied to prestressed concrete bridges exposed to chlorides. Sustainability, 10, 845. https://dx.doi.org/10.3390/su10030845.

Navarro, I.J., Yepes, V., Martí, J.V., 2018b. Social life cycle assessment of concrete bridge decks exposed to aggressive environments. Env. Imp. Assess. Rev, 72, 50-63. https://doi.org/10.1016/j.eiar.2018.05.003.

Nogueira, C.G., Leonel, E.D., Coda, H.B., 2012. Reliability algorithms applied to reinforced concrete structures durability assessment. Rev. IBRACON Estrut. Mater. 5, 440-50. https://dx.doi.org/10.1590/S1983-41952012000400003.

Ohama, Y., 1995. Handbook of Polymer-Modified Concrete and Mortars. William Andrew. ISBN: 9780815513582. 
Otsuki, N., Nishida, T., Yi, C., Nagata, T., 2014. Effect of blast furnace slag powder and fly ash on durability of concrete mixed with seawater. 4th International Conference on the durability of concrete structures, 24-26 July 2014. Purdue University, West Lafayette, In, USA.

Özkan, A., Günkaya, Z., Tok, G., Karacasulu, L., Metesoy, M., Banar, M., Kara, A., 2016. Life cycle assessment and life cycle cost analysis of magnesia spinel brick production. Sustainability, 8, 662. https://dx.doi.org/10.3390/su8070662.

Penadés-Plà, V., Martí, J.V., García-Segura, T., Yepes, V., 2017. Life cycle assessment: a comparison between two optimal post-tensioned concrete box-girder road bridges. Sustainability 9, 1864. https://dx.doi.org/10.3390/su9101864.

Petcherdchoo, A., 2012. Predicting service life and cost of chloride exposed concrete structures with repairs by cover replacement or silane treatment. Proceeding of the $17^{\text {th }}$ National Convention on Civil Eng.: Civil Engineering for Integrated Developments, Udon Thani, 9-11 May 2012.

Petcherdchoo, A., 2015. Environmental impacts of combined repairs on marine concrete structures. J. Adv. Conr. Technol., 13, 205-213. https://dx.doi.org/10.3151/jact.13.205.

Safi, M., Sundquist, H., Karoumi, R., 2015. Cost-efficient procurement of bridge infrastructures by incorporating life-cycle cost analysis with bridge management systems. J. Bridg. Eng. 20, 4014083. https://dx.doi.org/10.1061/(ASCE)BE.1943-5592.0000673.

Spanish Ministry of Public Works, 2008. EHE-08 Instrucción del Hormigón Estructural. ISBN: 978-84498-0899-9.

Swarr, T., Hunkeler, D., Klöpffer, W., Pesonen, H., Ciroth, A., Brent, A., Pagan, R., 2011. Environmental life-cycle costing: a code of practice. Int. J. Life Cycle Assess. 16, 389-391. https://dx.doi.org/10.1007/s11367-011-0287-5.

Titi, A., Biondini, F., 2016. On the accuracy of diffusion models for life-cycle assessment of concrete $\begin{array}{llll}\text { structures. } & \text { Struct. } & \text { Infrastruct. } & \text { Eng. }\end{array}$ httpss://dx.doi.org/10.1080/15732479.2015.1099110.

Valipour, M., Shekarchi, M., Arezoumandi, M., 2017. Chlorine diffusion resistivity of sustainable green concrete in harsh marine environments. J. Clean. Prod. 142, 4092-4100. http://dx.doi.org/10.1016/j.jclepro.2016.10.015.

Vedalakshmi, R., Saraswathy, V., Song, H.W., Palaniswamy, N., 2009. Determination of diffusion coefficient of chloride in concrete using Warburg diffusion coefficient. Corros. Sci. 51, 12991307. https://dx.doi.org/10.1016/j.corsci.2009.03.017.

Worrell, E., Price, L., Martin, N., Hendriks, C., Meida, L.O., 2001. Carbon dioxide emissions from the global cement industry. Annu. Rev. Energy Environ. 26, 303-329. http://dx.doi.org/10.1146/annurev.energy.26.1.303.

Yang, Z., Shi, X., Creighton, A.T., Peterson, M.M., 2009. Effect of styrene-butadiene rubber latex on the chloride permeability and microstructure of Portland cement mortar. Constr. Build. Mater. 23, 2283-90. https://dx.doi.org/10.1016/j.conbuildmat.2008.11.011.

Yepes, V., Martí, J.V., García-Segura, T., González-Vidosa, F., 2017. Heuristics in optimal detailed design of precast road bridges. Arch. Civ. Mech. Eng. 17, 738-49. http://dx.doi.org/10.1016/j.acme.2017.02.006.

Zastrow, P., Molina-Moreno, F., García-Segura, T., Martí, J., Yepes, V., 2017. Life cycle assessment of cost-optimized buttress earth-retaining walls: a parametric study. J. Clean. Prod. 140, 1037-48. https://dx.doi.org/10.1016/j.jclepro.2016.10.085.

Zhang, J.Z., Buenfeld, N.R., 2000. Chloride profiles in surface-treated mortar specimens. Constr. Build. Mater. 14, 359-64. https://dx.doi.org/10.1016/S0950-0618(00)00043-X. 
Zhang, Y.R., Wu, W.J., Wang, Y.F., 2016. Bridge life cycle assessment with data uncertainty. Int. J. LifeCycle Assess. 21, 569-576. doi: 10.1007/s11367-016-1035-7. 


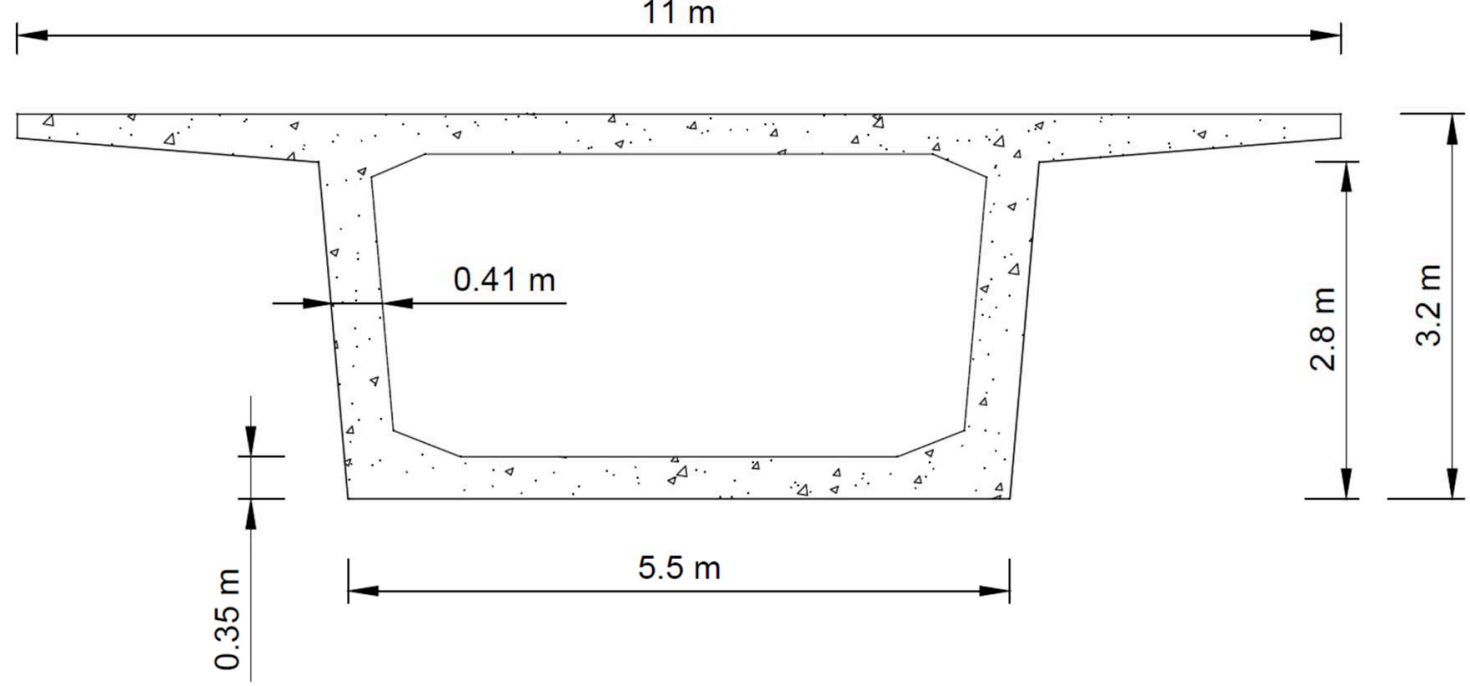

Fig. 1. Cross-section of the concrete bridge deck at Ensenada do Engano (dimensions in m) 


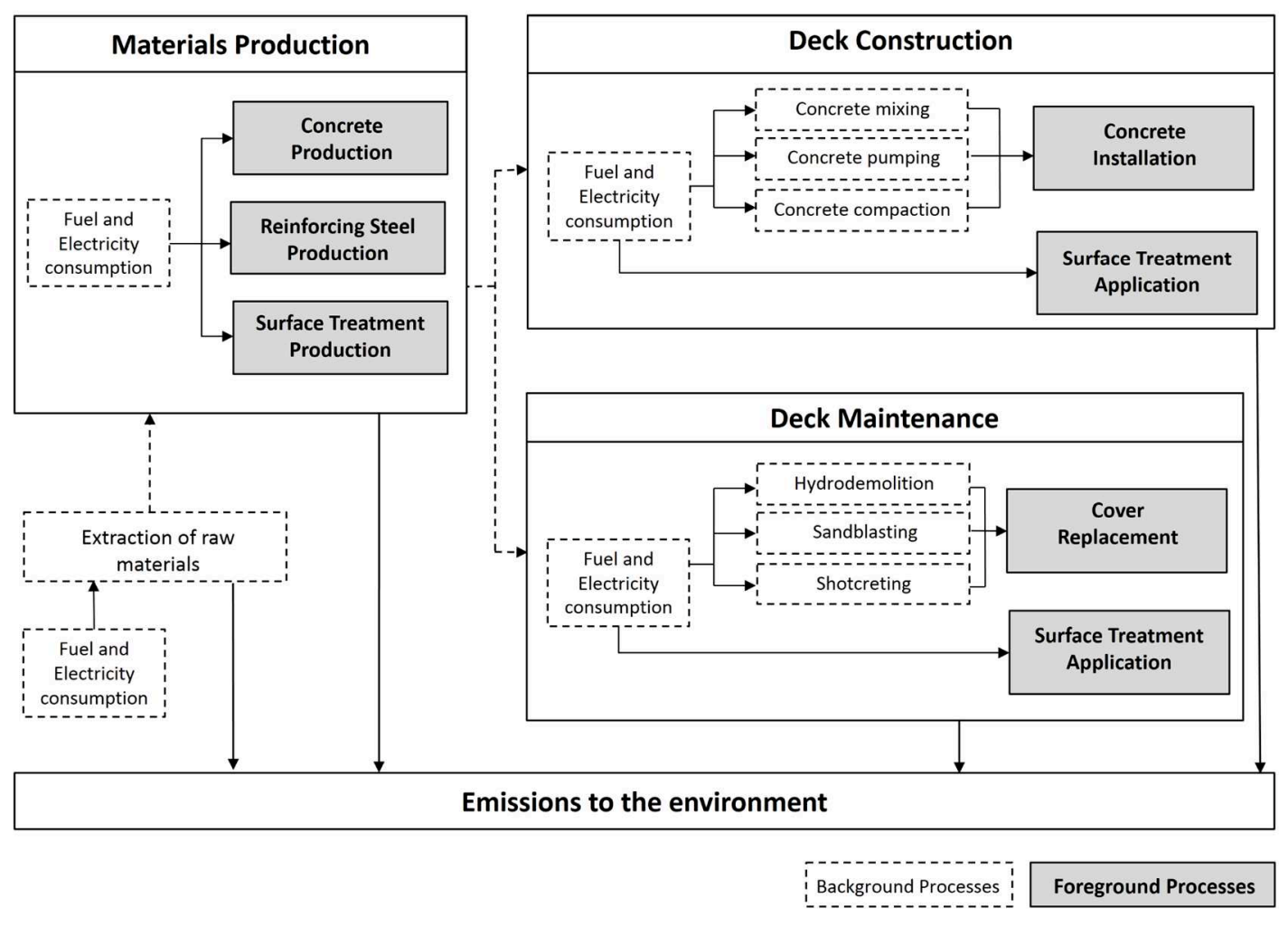

Fig. 2. System boundaries considered in the assessment 


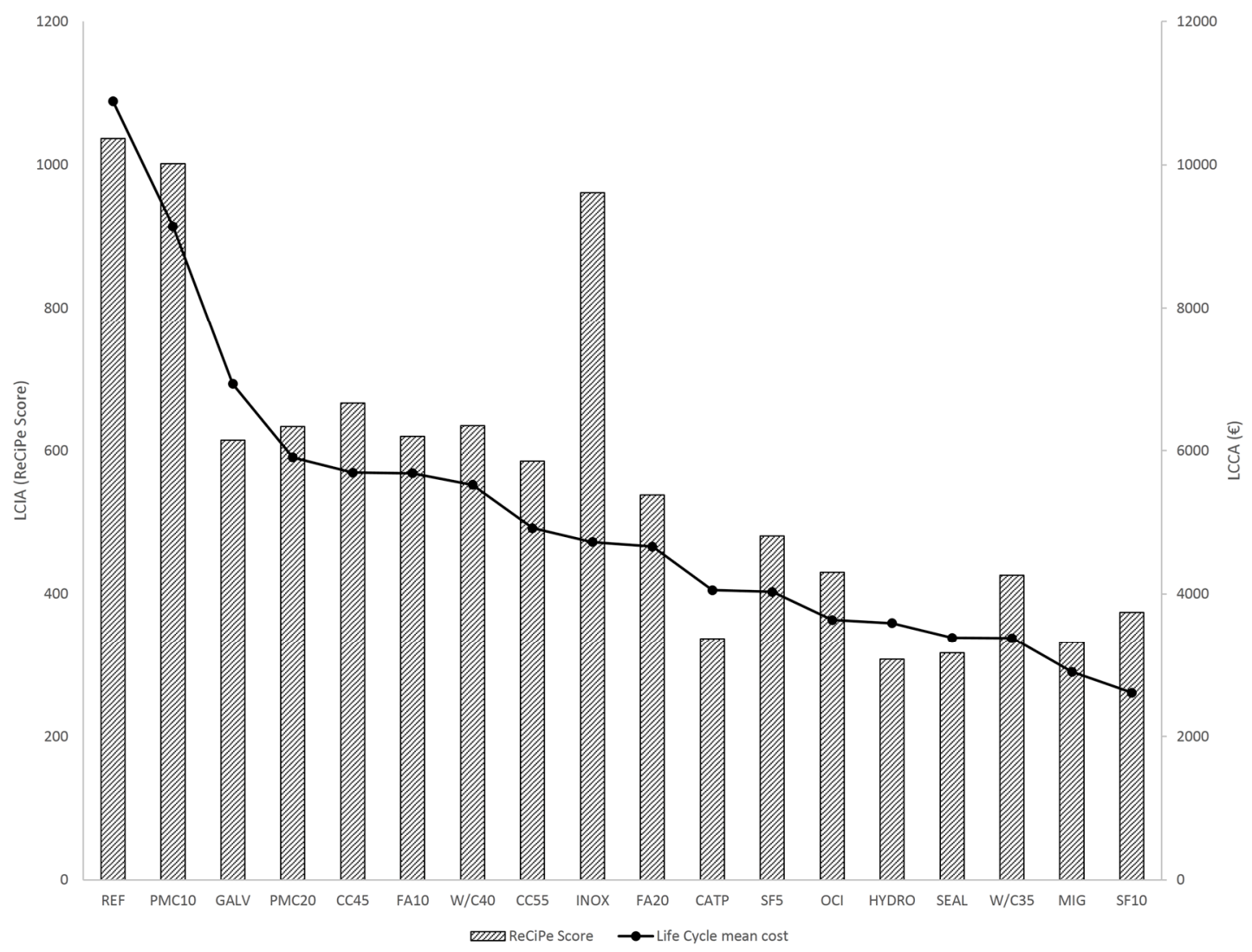

Fig. 3. Assessment results assuming cost optimized maintenance strategies 


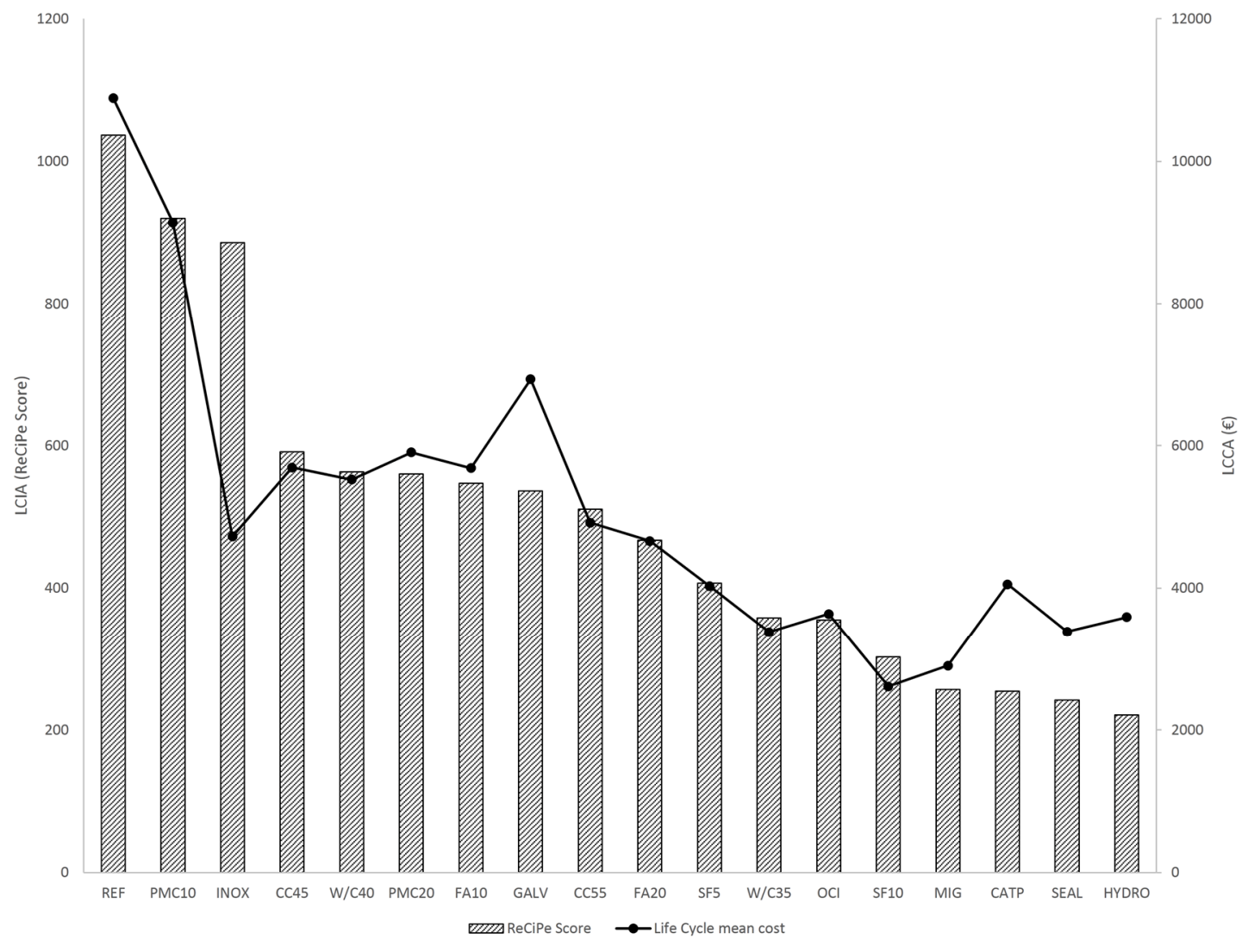

Fig. 4. Assessment results assuming environmentally optimized maintenance strategies

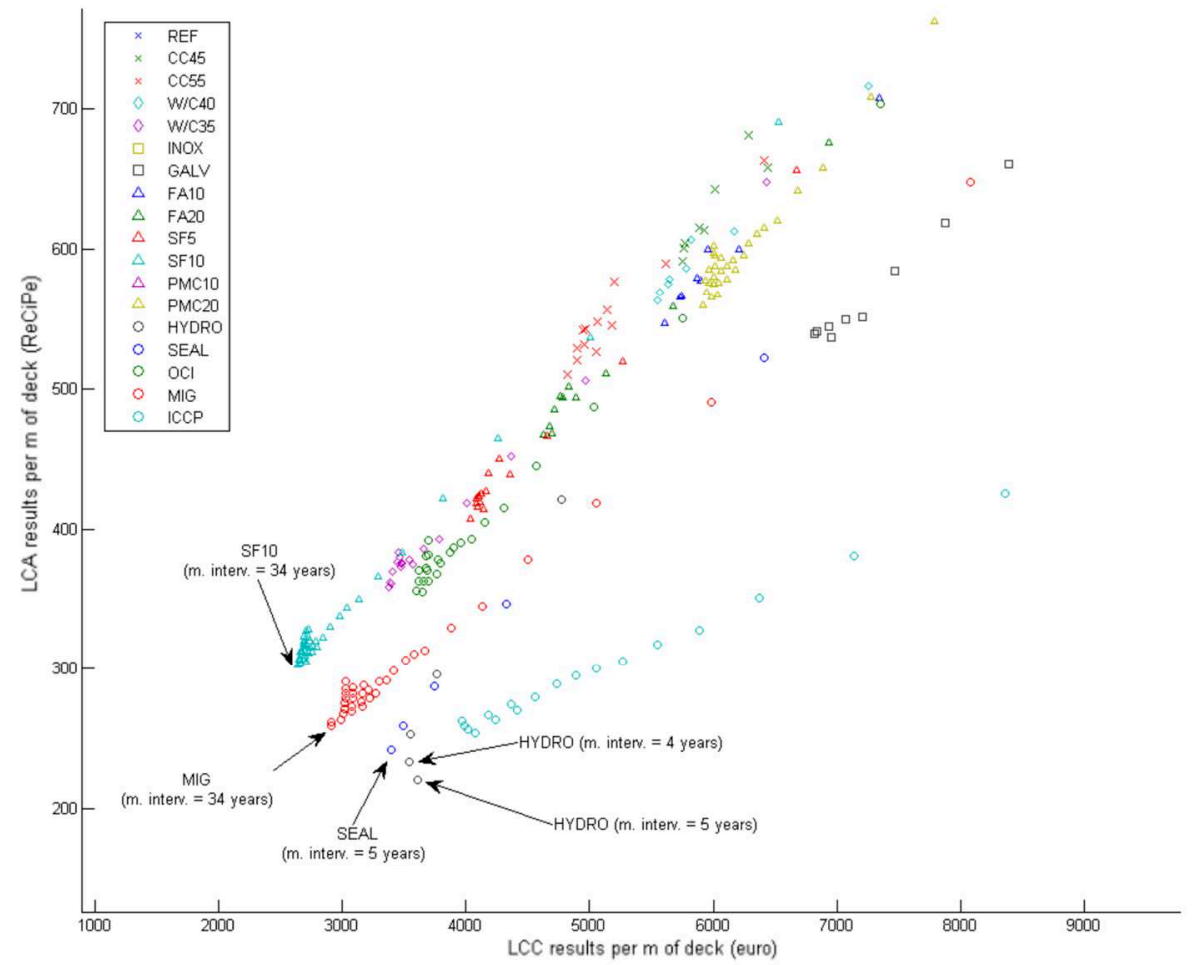

Fig. 5. Representative solutions of the Pareto optimal set 
Table 1

Alternative concrete mixes assumed in the preventive designs

\begin{tabular}{|c|c|c|c|c|c|c|c|c|c|c|}
\hline $\begin{array}{l}\text { Concrete mix } \\
\text { components }\end{array}$ & $\mathrm{REF}^{\mathrm{a}}$ & $\mathrm{W} / \mathrm{C} 40$ & W/C35 & SF5 & SF10 & FA10 & FA20 & PMC10 & PMC20 & OCI \\
\hline Cement $\left(\mathrm{kg} / \mathrm{m}^{3}\right)$ & 400 & 400 & 400 & 342.2 & 302.2 & 370.2 & 358.2 & 400 & 400 & 400 \\
\hline Water $\left(1 / \mathrm{m}^{3}\right)$ & 172 & 160 & 140 & 172 & 172 & 172 & 172 & 172 & 172 & 172 \\
\hline Gravel $\left(\mathrm{kg} / \mathrm{m}^{3}\right)$ & 926.7 & 993.9 & 1016.9 & 980.1 & 980.1 & 980.1 & 980.1 & 926.7 & 926.7 & 926.7 \\
\hline Sand $\left(\mathrm{kg} / \mathrm{m}^{3}\right)$ & 827.9 & 993.2 & 1024.2 & 1007.5 & 1024.9 & 965.7 & 941.3 & 827.9 & 827.9 & 827.9 \\
\hline Fly Ash $\left(\mathrm{kg} / \mathrm{m}^{3}\right)$ & - & - & - & - & - & 40 & 80 & - & - & - \\
\hline Silica Fume $\left(\mathrm{kg} / \mathrm{m}^{3}\right)$ & - & - & - & 20 & 40 & - & - & - & - & - \\
\hline $\begin{array}{l}\text { Styrene Butadiene } \\
\text { Latex }\left(\mathrm{kg} / \mathrm{m}^{3}\right)\end{array}$ & - & - & - & - & - & - & - & 40 & 80 & - \\
\hline $\begin{array}{l}\text { Organic Inhibitor } \\
\qquad\left(\mathrm{kg} / \mathrm{m}^{3}\right)\end{array}$ & - & - & - & - & - & - & - & - & - & 12 \\
\hline $\mathrm{f}_{\mathrm{ck}}(\mathrm{MPa})$ & 32 & 39 & 47 & 32 & 32 & 32 & 32 & 42 & 42 & 32 \\
\hline $\mathrm{E}_{\mathrm{c}}(\mathrm{GPa})$ & 29 & 31 & 32 & 29 & 29 & 29 & 29 & 31 & 31 & 29 \\
\hline
\end{tabular}

Notes:

${ }^{\mathrm{a}}$ Concrete in alternatives CC45, CC55, INOX, GALV, MIG, HYDRO, SEAL, and ICCP are based on this reference mix

Table 2

Ecoinvent datasets considered for modelling inventory data related to the assumed construction materials

\begin{tabular}{|c|c|}
\hline Inventory data concept & Ecoinvent dataset \\
\hline Cement & Cement production, Portland $[\mathrm{kg}]$ \\
\hline Gravel & Gravel production, crushed $[\mathrm{kg}]$ \\
\hline Sand & Silica sand production $[\mathrm{kg}]$ \\
\hline Plasticiser & Plasticiser production, for concrete, based on sulfonated melamine formaldehyde $[\mathrm{kg}]$ \\
\hline Inhibitor & EDTA production $[\mathrm{kg}]^{\mathrm{a}}$ \\
\hline Styrene Butadiene Latex & Latex production $[\mathrm{kg}]$ \\
\hline Hydrophobic treatment ${ }^{b}$ & Ethoxylated alcohol (AE3) production, petrochemical $[\mathrm{kg}]$; Silicone product production $[\mathrm{kg}]$ \\
\hline Sealant treatment ${ }^{\mathrm{c}}$ & Cement production, Portland [kg]; Silica sand production $[\mathrm{kg}]$; Butyl acrylate production $[\mathrm{kg}]$ \\
\hline Reinforcing steel & Reinforcing steel production $[\mathrm{kg}]$ \\
\hline Stainless reinforcement & Steel production, chromium steel $18 / 8$, hot rolled $[\mathrm{kg}]$ \\
\hline Galvanized reinforcement & Reinforcing steel production $[\mathrm{kg}]$; Zinc coating, coils $\left[\mathrm{m}^{2}\right]$ \\
\hline
\end{tabular}

Notes:

${ }^{a}$ Used for both design alternative MIG and design alternative OCI

${ }^{\mathrm{b}}$ Acc. to manufacturer's specifications: $0.65 \mathrm{~kg}$ water $+0.35 \mathrm{~kg}$ silicone $+0.035 \mathrm{~kg}$ surfactant per $\mathrm{kg}$ of treatment

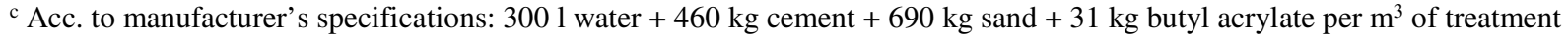


Table 3

Life cycle inventory data on process performances and energy consumptions

\begin{tabular}{llcl}
\hline Process & Concept & Value & \\
\hline Concrete mixing $^{\mathrm{a}}$ & Performance & $7.2 \mathrm{~min} / \mathrm{m}^{3}$ & Zastrow et al., 2017 \\
Galvanization $^{\mathrm{b}}$ & Electricity consumption & $0.3 \mathrm{kWh} / \mathrm{kg}$ & Blakey and Beck, 2004 \\
Emulsifying mixer $^{\mathrm{b}}$ & Electricity consumption & $0.025 \mathrm{kWh} / \mathrm{kg}$ & Acc. to manufacturer's specifications \\
Hydrophobic treatment $^{\mathrm{b}}$ & Power & $1.3 \mathrm{~kW}$ & Acc. to manufacturer's specifications \\
& Performance & $120 \mathrm{l} / \mathrm{h}$ & \\
Cathodic Protection $^{\mathrm{b}}$ & Electricity consumption & $0.41 \mathrm{kWh} / \mathrm{m}^{2} /$ year & Bertolini et al., 2009 \\
Hidrodemolition $^{\mathrm{b}}$ & Power & $0.750 \mathrm{~kW}$ & Acc. to manufacturer's specifications \\
& Performance & $0.6 \mathrm{~m} / \mathrm{h}$ & \\
Sandblasting $^{\mathrm{a}}$ & Fuel consumption & $2.27 \mathrm{l} / \mathrm{h}$ & Millman and Giancaspro, 2012 \\
& Performance & $13.2 \mathrm{~m} / \mathrm{h}$ & \\
Shotcreting $^{\mathrm{a}}$ & Power & $26.5 \mathrm{~kW}$ & Acc. to manufacturer's specifications \\
& Performance & $18 \mathrm{~m}^{3} / \mathrm{h}$ & \\
\hline
\end{tabular}

Notes:

a Fuel consumption has been assimilated to Ecoinvent concept "Machine operation, diesel, >= 74.57 kW, generators [hours]"

${ }^{\mathrm{b}}$ Electricity consumption has been assimilated to Ecoinvent concept "Electricity, medium voltage [kWh]"

Table 4

Assumed transport distances and transport modes

\begin{tabular}{lccc}
\hline Activity or production process & $\begin{array}{c}\text { Lorry } \\
(\mathrm{km})\end{array}$ & $\begin{array}{c}\text { Rail } \\
(\mathrm{km})\end{array}$ & $\begin{array}{c}\text { Total } \\
(\mathrm{km})\end{array}$ \\
Aggregates $^{\mathrm{a}}$ & 10.6 & - & 10.6 \\
Portland Cement $^{\mathrm{a}}$ & 16.2 & - & 16.2 \\
Fly Ash $^{\mathrm{a}}$ & 34.8 & - & 34.8 \\
Silica Fume $^{\mathrm{a}}$ & 71.2 & - & 71.2 \\
Polymer $^{\mathrm{a}}$ & 133 & 532 & 665 \\
Plastiziser $^{\mathrm{a}}$ & 133 & 532 & 665 \\
Corrosion inhibitor aditive $^{\mathrm{a}}$ & 122 & 488 & 610 \\
Reference concrete $^{\mathrm{b}}$ & 43.9 & - & 43.9 \\
Polymer modified concrete $^{\mathrm{b}}$ & 43.9 & - & 43.9 \\
Fly ash concrete $^{\mathrm{b}}$ & 43.9 & - & 43.9 \\
Silica fume concrete $^{\mathrm{b}}$ & 43.9 & - & 43.9 \\
Carbon steel reinforcement $^{\mathrm{c}}$ & 28.6 & 114.4 & 143 \\
Stainless steel reinforcement $^{\mathrm{c}}$ & 124 & 496 & 620 \\
Galvanized steel reinforcement $^{\mathrm{c}}$ & 28.6 & 114.4 & 143 \\
Hydrophobic product $^{\mathrm{c}}$ & 138.6 & 554.4 & 693 \\
Sealant product $^{\mathrm{c}}$ & 138.6 & 554.4 & 693 \\
Corrosion inhibitor aditive $^{\mathrm{c}}$ & 127.4 & 509.6 & 637 \\
Cathodic Protection System $^{\mathrm{c}}$ & 126.8 & 507.2 & 634 \\
\hline Notes: $^{\mathrm{n}}$ & & &
\end{tabular}

Notes:

a Distance from production facility to concrete plant

${ }^{\mathrm{b}}$ Distance from concrete plant to installation site

${ }^{\mathrm{c}}$ Distance from production facility to installation site 
Table 5

Assumed carbonation rate coefficient $k$ depending on the concrete type considered, according to Fib Bulletin 34 (Fib, 2006)

\begin{tabular}{ccccccccc}
\hline Design alternative & REF & W/C40 & W/C35 & FA10 & FA20 & SF5 & SF10 & OCI \\
\hline $\mathrm{k}\left(\mathrm{x} 10^{-3} \mathrm{~m} /\right.$ year $\left.^{0.5}\right)$ & 1.83 & 1.42 & 0.8 & 1.52 & 1.1 & 1.89 & 1.5 & 1.83 \\
\hline
\end{tabular}

\section{Table 6}

Unit costs $(€)$ considered in the LCCA

$\mathrm{m}^{3}$ of concrete HA30

83.62

$\mathrm{m}^{3}$ of concrete HA30 $(\mathrm{w} / \mathrm{c}=0,4)$

97.99

$\mathrm{m}^{3}$ of concrete HA30 (w/c=0,35)

104.26

$\mathrm{m}^{3}$ of concrete $\mathrm{HA} 30+10 \% \mathrm{FA}$

101.63

$\mathrm{m}^{3}$ of concrete $\mathrm{HA} 30+20 \% \mathrm{FA}$

101.23

$\mathrm{m}^{3}$ of concrete $\mathrm{HA} 30+5 \% \mathrm{SF}$

131.40

$\mathrm{m}^{3}$ of concrete $\mathrm{HA} 30+10 \% \mathrm{SF}$

137.58

$\mathrm{m}^{3}$ of concrete HA30+Organic corrosion inhibitor

164.30

1 of styrene butadiene rubber latex

$\mathrm{kg}$ of steel (B $500 \mathrm{~S}$ )

$\mathrm{kg}$ of stainless steel

$\mathrm{kg}$ of galvanized steel

$\mathrm{m}^{2}$ of hydrophobic treatment

17.78

$\mathrm{m}^{2}$ of sealant treatment

$\mathrm{m}^{2}$ of inhibitor surface treatment

$\mathrm{m}^{2}$ of cathodic protection

$\mathrm{m}^{2}$ of hydrodemolished cover ${ }^{\mathrm{a}}$

$\mathrm{m}^{2}$ of sandblasting

$\mathrm{m}^{2}$ of reinforcement priming

Notes:

${ }^{\text {a }}$ The cost of cover demolition depends on the depth to be demolished. The value shown here corresponds to a $30 \mathrm{~mm}$ deep cover completely replaced 
Table 7

Durability parameters assumed for the alternative designs

\begin{tabular}{|c|c|c|c|c|c|c|c|c|}
\hline $\begin{array}{l}\text { Design } \\
\text { alternative }\end{array}$ & $\begin{array}{c}\text { Do } \\
\text { Mean }\end{array}$ & $\begin{array}{c}\left(\mathrm{x} 10^{-12} \mathrm{~m}^{2} / \mathrm{s}\right) \\
\text { Std. Dev. }\end{array}$ & $\begin{array}{l}\text { C crít } \\
\text { Mean }\end{array}$ & $\begin{array}{c}(\%) \\
\text { Std. Dev. }\end{array}$ & $\begin{array}{c}\mathrm{r}_{\mathrm{x}} \\
\text { Mean }\end{array}$ & $\begin{array}{c}(\mathrm{mm}) \\
\text { Std. Dev. }\end{array}$ & $\begin{array}{l}\text { Mean } \\
\text { service life } \\
\text { (years) }\end{array}$ & Sources \\
\hline REF & 9.56 & 1.02 & 0.6 & 0.1 & 35 & 1.75 & 4 & \multirow[t]{3}{*}{$\begin{array}{c}\text { Spanish Ministry of Public } \\
\text { Works, } 2008\end{array}$} \\
\hline $\mathrm{CC} 45$ & 9.56 & 1.02 & 0.6 & 0.1 & 45 & 2.25 & 10 & \\
\hline CC55 & 9.56 & 1.02 & 0.6 & 0.1 & 55 & 2.75 & 15 & \\
\hline $\mathrm{W} / \mathrm{C} 40$ & 5.90 & 0.48 & 0.6 & 0.1 & 30 & 1.75 & 9 & \multirow{2}{*}{$\begin{array}{l}\text { Vedalakshmi et al., 2009; } \\
\text { Cheewaket et al., } 2014\end{array}$} \\
\hline W/C35 & 3.84 & 0.29 & 0.6 & 0.1 & 30 & 1.75 & 20 & \\
\hline INOX & 9.56 & 1.02 & 5 & 0.94 & 30 & 1.75 & - & Bertolini et al., 1996 \\
\hline GALV & 9.56 & 1.02 & 1.2 & 0.21 & 30 & 1.75 & 12 & Darwin et al., 2009 \\
\hline OCI & 3.81 & 0.29 & 0.71 & 0.1 & 35 & 1.75 & 26 & \multirow{2}{*}{ Bolzoni et al., 2014} \\
\hline MIG & 2.72 & 0.22 & 0.6 & 0.1 & 35 & 1.75 & 36 & \\
\hline SF5 & 3.16 & 0.25 & 0.38 & 0.06 & 35 & 1.75 & 16 & \multirow{2}{*}{$\begin{array}{c}\text { Frederiksen, 2000; Manera et } \\
\text { al., } 2008\end{array}$} \\
\hline SF10 & 1.32 & 0.17 & 0.22 & 0.03 & 35 & 1.75 & 42 & \\
\hline FA10 & 5.89 & 0.48 & 0.6 & 0.1 & 35 & 1.75 & 10 & \multirow{2}{*}{ Otsuki et al., 2014} \\
\hline FA20 & 5.00 & 0.39 & 0.6 & 0.1 & 35 & 1.75 & 12 & \\
\hline PMC10 & 7.00 & 0.61 & 0.6 & 0.1 & 35 & 1.75 & 7 & \multirow{2}{*}{$\begin{array}{c}\text { Ohama, 1995; Yang et al., } \\
2009\end{array}$} \\
\hline PMC20 & 2.91 & 0.23 & 0.6 & 0.1 & 35 & 1.75 & 32 & \\
\hline ICCP & 9.56 & 1.02 & 2.49 & 0.1 & 35 & 1.75 & $53^{\mathrm{a}}$ & Bertolini et al., 2009 \\
\hline HYDRO & 7.39 & 0.67 & 0.6 & 0.1 & 35 & 1.75 & $5^{\mathrm{b}}$ & Zhang and Buenfeld, 2000 \\
\hline SEAL & 4.66 & 0.35 & 0.6 & 0.1 & 35 & 1.75 & $11^{\mathrm{b}}$ & Medeiros et al., 2012 \\
\hline
\end{tabular}

Notes:

${ }^{a}$ According to manufacturer specifications, service life of the titanium anode is 20 years

${ }^{\mathrm{b}}$ According to manufacturer specifications, surface treatments shall be reapplied every 5 years to ensure durability 
Table 8

Assessment results considering LCC optimized maintenance intervals

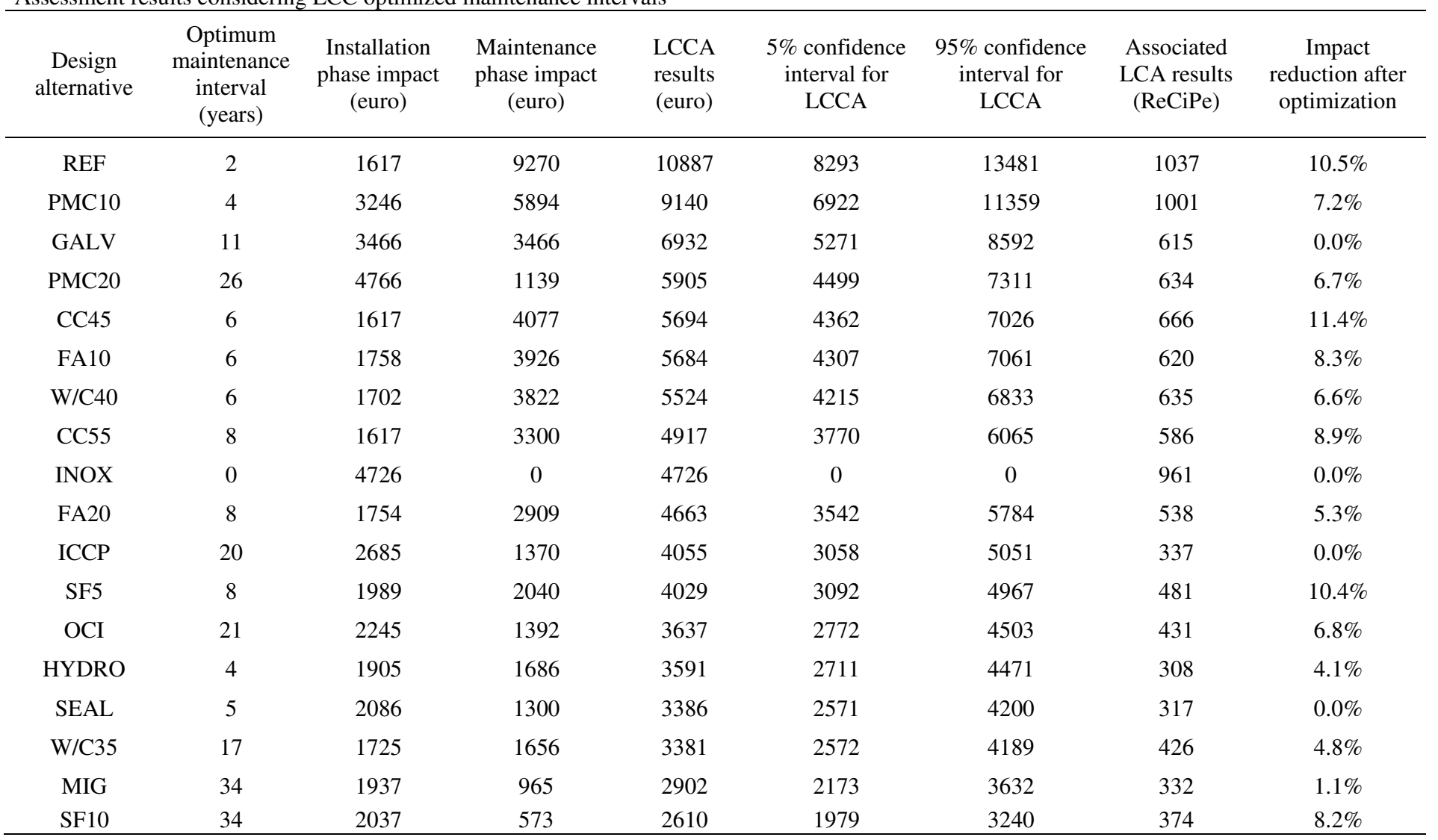


Table 9

Assessment results considering LCA optimized maintenance intervals

\begin{tabular}{|c|c|c|c|c|c|c|c|c|c|}
\hline $\begin{array}{l}\text { Design } \\
\text { alternative }\end{array}$ & $\begin{array}{l}\text { Optimum } \\
\text { maintenance } \\
\text { interval } \\
\text { (years) }\end{array}$ & $\begin{array}{c}\text { Installation } \\
\text { phase impact } \\
(\mathrm{ReCiPe})\end{array}$ & $\begin{array}{c}\text { Maintenance } \\
\text { phase impact } \\
\text { (ReCiPe) }\end{array}$ & $\begin{array}{c}\text { Demolition } \\
\text { phase impact } \\
(\mathrm{ReCiPe})\end{array}$ & $\begin{array}{c}\mathrm{LCA} \\
\text { results } \\
(\mathrm{ReCiPe})\end{array}$ & $\begin{array}{c}5 \% \\
\text { confidence } \\
\text { interval for } \\
\text { LCA }\end{array}$ & $\begin{array}{c}95 \% \\
\text { confidence } \\
\text { interval for } \\
\text { LCA }\end{array}$ & $\begin{array}{l}\text { Associated } \\
\text { LCCA } \\
\text { results } \\
\text { (euro) }\end{array}$ & $\begin{array}{c}\text { Impact reduction } \\
\text { after } \\
\text { optimization }\end{array}$ \\
\hline REF & 2 & 245 & 867 & -75 & 1037 & 993 & 1082 & 10887 & $12.6 \%$ \\
\hline PMC10 & 4 & 368 & 626 & -74 & 920 & 929 & 993 & 9140 & $8.8 \%$ \\
\hline INOX & 0 & 961 & 0 & -75 & 886 & 900 & 964 & 4726 & $0.0 \%$ \\
\hline $\mathrm{CC} 45$ & 6 & 245 & 421 & -75 & 591 & 605 & 638 & 5694 & $17.6 \%$ \\
\hline $\mathrm{W} / \mathrm{C} 40$ & 6 & 258 & 377 & -72 & 563 & 546 & 591 & 5524 & $10.3 \%$ \\
\hline PMC20 & 26 & 494 & 140 & -74 & 560 & 591 & 628 & 5905 & $23.2 \%$ \\
\hline FA10 & 6 & 253 & 367 & -73 & 547 & 542 & 566 & 5684 & $12.7 \%$ \\
\hline GALV & 8 & 275 & 337 & -75 & 537 & 519 & 556 & 6932 & $0.9 \%$ \\
\hline CC55 & 8 & 245 & 340 & -75 & 511 & 557 & 584 & 4917 & $11.9 \%$ \\
\hline FA20 & 8 & 256 & 282 & -71 & 467 & 513 & 526 & 4663 & $8.6 \%$ \\
\hline SF5 & 8 & 277 & 204 & -74 & 407 & 455 & 485 & 4029 & $17.4 \%$ \\
\hline W/C35 & 17 & 259 & 167 & -68 & 358 & 387 & 422 & 3381 & $12.9 \%$ \\
\hline OCI & 17 & 289 & 141 & -75 & 355 & 345 & 357 & 3637 & $20.6 \%$ \\
\hline SF10 & 34 & 307 & 68 & -72 & 302 & 432 & 460 & 2610 & $23.3 \%$ \\
\hline MIG & 34 & 249 & 83 & -75 & 257 & 249 & 258 & 2902 & $5.9 \%$ \\
\hline ICCP & 17 & 246 & 83 & -75 & 254 & 247 & 255 & 4055 & $9.0 \%$ \\
\hline SEAL & 5 & 247 & 70 & -75 & 242 & 235 & 243 & 3386 & $0.0 \%$ \\
\hline HYDRO & 5 & 246 & 50 & -75 & 221 & 217 & 229 & 3591 & $0.0 \%$ \\
\hline
\end{tabular}


Table 10

Uncertainty derived from the chosen discount rate

\begin{tabular}{|c|c|c|c|c|c|c|c|}
\hline $\begin{array}{l}\text { Discount } \\
\text { rate }\end{array}$ & \multicolumn{7}{|c|}{ Set of Pareto optimal solutions } \\
\hline $2 \%$ & SF10 (34 years) $)^{a}$ & MIG (34 years) & SEAL (5 years) & HYDRO (4 years) & HYDRO (5 years) & & \\
\hline $3 \%$ & SF10 (35 years) & MIG (34 years) & SEAL (4 years) & HYDRO (4 years) & & & \\
\hline $4 \%$ & SF10 (41 years) & SF10 (37 years) & MIG (36 years) & MIG (35 years) & SEAL (5 years) & HYDRO (4 years) & HYDRO (5 years) \\
\hline
\end{tabular}

Notes:

a The resulting optimal maintenance interval is given in brackets

\section{Table 11}

Uncertainty derived from the chosen impact assessment methodology

\begin{tabular}{|c|c|c|c|c|c|}
\hline Impact Assessment & \multicolumn{5}{|c|}{ Set of Pareto optimal solutions } \\
\hline $\mathrm{ReCiPe}$ & SF10 (34 years $)^{\mathrm{a}}$ & MIG (34 years) & SEAL (5 years) & HYDRO (4 years) & HYDRO (5 years) \\
\hline EPS & SF10 (34 years) & MIG (34 years) & SEAL (5 years) & HYDRO (4 years) & HYDRO (5 years) \\
\hline
\end{tabular}

\section{Notes:}

a The resulting optimal maintenance interval is given in brackets 